\title{
CYP27B1 Gene
}

National Cancer Institute

\section{Source}

National Cancer Institute. CYP27B1 Gene. NCI Thesaurus. Code C40073.

This gene is involved in vitamin D metabolism and calcium homeostasis. 